\title{
Case Report \\ Cerebral Venous Thrombosis in the Setting of Malignancy: Case Report and Review of the Literature
}

\author{
Constantine N. Logothetis ${ }^{1}$ and Charles Pizanis $\mathbb{i D}^{2}$ \\ ${ }^{1}$ Department of Internal Medicine, University of South Florida Morsani College of Medicine, 17 Davis Blvd, Suite 308, Tampa, \\ FL 33606, USA \\ ${ }^{2}$ Division of Hospital Medicine Department of Internal Medicine, University of New Mexico School of Medicine, \\ University of New Mexico, MSC10 5550, Albuquerque, NM 87131, USA \\ Correspondence should be addressed to Charles Pizanis; cpizanis@salud.unm.edu
}

Received 25 May 2020; Accepted 28 August 2020; Published 18 September 2020

Academic Editor: Kostas Konstantopoulos

Copyright (c) 2020 Constantine N. Logothetis and Charles Pizanis. This is an open access article distributed under the Creative Commons Attribution License, which permits unrestricted use, distribution, and reproduction in any medium, provided the original work is properly cited.

Cerebral venous thrombosis (CVT) is a rare condition that can be difficult to diagnose due to its vague and nonspecific symptoms. It is even more unusual to identify CVT in association with malignancy. Given the rarity of this disease, treatment and management of CVT in the setting of malignancy is not well defined. This case report and review of the literature addresses the epidemiology, pathophysiology, and medical treatment for malignancy-related CVT.

\section{Introduction}

Venous thromboembolism (VTE) is a common complication of cancer and cancer-related treatment. Among the possible VTEs that can occur are thromboses of the dural sinuses or cerebral veins. Cerebral venous thrombosis (CVT) is an uncommon clinical entity and is often difficult to identify due to its vague and nonspecific findings. Management of CVT can similarly pose a challenge for clinicians given the risk of bleeding complications with treatment. This case highlights a patient whose diagnosis of CVT was initially missed as was the underlying etiology of the disorder. This article reviews the epidemiology, pathophysiology, and medical management of CVT in patients with malignancy.

\section{Case Presentation}

A 60-year-old woman with a medical history of type 2 diabetes mellitus, papillary thyroid cancer status post resection, and hypertension presented to a referring hospital with worsening headaches and visual disturbances. For four months prior to her presentation, she had experienced intermittent unilateral, pulsating headaches as well as visual disturbances in the right eye. Upon arrival to the emergency department, she was febrile and noted to have meningismus. CBC revealed white blood cells at 9,800/L, hemoglobin at $12.9 \mathrm{~g} / \mathrm{dL}$, and platelets at $223,000 / \mathrm{uL}$. Lumbar puncture was performed with a cerebrospinal fluid (CSF) profile demonstrating colorless fluid, total nucleated cells $43 / \mathrm{mm}^{3}$, red blood cells $4 / \mathrm{mm}^{3}$, glucose $134 \mathrm{mg} / \mathrm{dL}$, total protein $50 \mathrm{mg} / \mathrm{dL}$, and an opening pressure of $21 \mathrm{~cm}$ H20. CSF herpes simplex virus $1 / 2$, West Nile virus, cytomegalovirus, enterovirus, varicella zoster virus PCRs, venereal disease research laboratory (VDRL), and coccidioides antibodies were negative or nonreactive, respectively. Serum HIV 1/2 antibodies, QuantiFERON-TB Gold, and autoimmune panel consisting of antinuclear antibody, rheumatoid factor, anti-mitochondrial antibody, and macrophage 2 antibodies were also nonrevealing. Magnetic resonance imaging (MRI) of the brain was obtained at the time which showed acute-to-subacute thrombosis of the right transverse sinuses (Figure 1). Given her constellation of symptoms and negative infectious and autoimmune workup, she was initially treated for aseptic meningitis and discharged home with warfarin anticoagulation for the thrombosis. Her symptoms did not fully resolve, however, and she was readmitted one week later to the hospital for further evaluation and workup. 


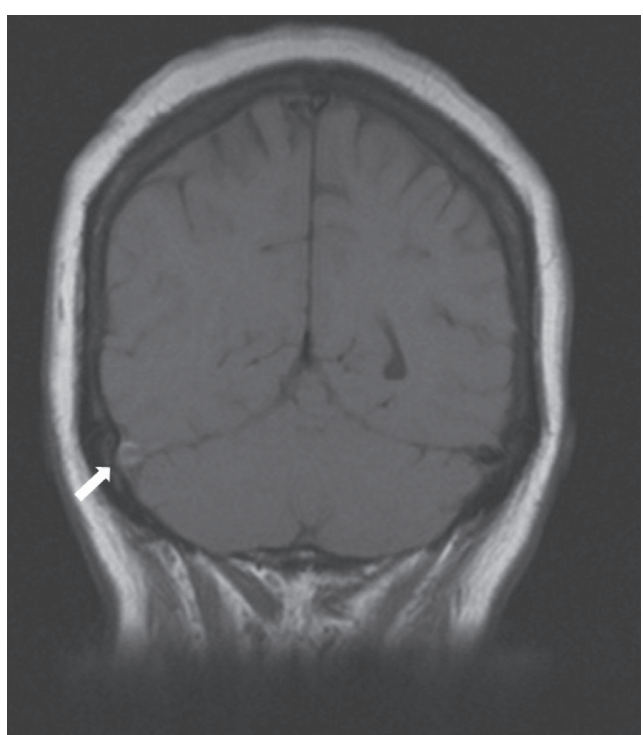

(a)

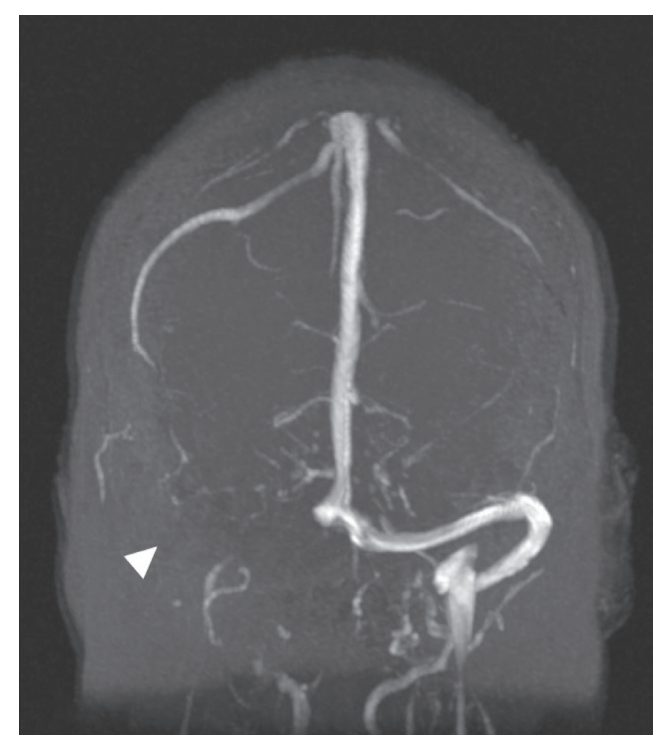

(b)

FIGURE 1: Magnetic resonance imaging demonstrating flow void at right transverse sinus (arrow) and absence of contrast (arrowhead) along transverse sinus consistent with transverse sinus thrombus.

On readmission, her $\mathrm{CBC}$ demonstrated elevated white blood cells at 17,000/L (38\% polymorphonuclear cells, $34 \%$ lymphocytes, and $23 \%$ variant lymphocytes). Due to the presence of variant lymphocytes noted at that time, a peripheral blood smear was obtained which revealed precursor B-cells and 30\% circulating blasts consistent with B-cell acute lymphoblastic leukemia (ALL). A repeat lumbar puncture was performed with CSF profile demonstrating total nucleated cells $728 / \mathrm{mm}^{3}$, red blood cells $0 / \mathrm{mm}^{3}$, glucose $93 \mathrm{mg} / \mathrm{dL}$, and total protein $42 \mathrm{mg} / \mathrm{dL}$. CSF flow cytometry demonstrated $97 \%$ blasts expressing CD34, CD19, bright CD10, and dim CD33 consistent with CNS involvement. After consultation with hematology, the patient was started on the ALL202 protocol with cyclophosphamide, daunorubicin, vincristine, methotrexate, cytarabine, and imatinib (given $\mathrm{Ph}$ chromosome positivity) as well as intrathecal methotrexate. During her hospitalization, her dural sinus thrombosis was treated with therapeutic-dosing enoxaparin at $1.5 \mathrm{mg} / \mathrm{kg} /$ day $(100 \mathrm{mg})$.

During the course of her ALL treatment, the patient experienced repeated episodes of thrombocytopenia with clinical concerns for subarachnoid hemorrhage. After a year and a half of anticoagulation with enoxaparin, a follow-up MRI was obtained which demonstrated stability in the thrombosis since initial diagnosis. Because of the chronicity of the thrombus and the ongoing bleeding concerns, enoxaparin was discontinued. The patient underwent subsequent brain imaging during the course of her ALL treatment which did not demonstrate any increase in size of the dural sinus thrombosis despite lack of anticoagulation.

\section{Discussion}

Due to the rare nature the disease, there is little literature on the epidemiology, pathophysiology, and management of malignancy-related CVT. The prevalence of CVT in patients with malignancy is believed to be approximately $0.3 \%[1,2]$. Malignancy-related thromboses of the dural sinus or cerebral veins are thought to represent roughly $7.4 \%$ of all CVT cases, with cancer increasing risk for CVT roughly 5-fold[3]. Hematologic malignancies appear to be implicated more so than solid organ malignancies; however, the underlying reasons for this are not completely understood [4]. CVT has also been described in the setting of antineoplastic therapy. Several agents have been reported in the development of this condition including bevacizumab and lenalidomide $[1,5]$.

3.1. Pathophysiology. The pathophysiology behind the development of CVT is complex and follows Virchow's triad. While more clearly described in the setting of infection wherein localized inflammatory processes related to septic emboli, thrombi formation, and localized infection are thought to drive thrombus formation, the pathogenesis of CVT in the setting of malignancy is not well defined [6]. Several potential mechanisms have been proposed including direct tumor compression, tumor invasion, and the hypercoagulable state of malignancy $[2,7,8]$. In the absence of tumor compression or invasion, malignancy-related prothrombotic states are thought to drive development of VTE via a variety of mechanisms including a tumor's ability to increase the expression of tissue factor (TF), cancer procoagulant, and inflammatory cytokines as well as to downregulate the expression of thrombomodulin and the protein C system [9].

3.2. Medical Management. The treatment strategy for patients with malignancy-related CVT can be challenging. Similar to other causes of CVT, malignancy-related CVT carries risks of hemorrhage and hematoma formation. 
TABLE 1: Review of the literature describing sinus thromboses in malignancies.

\begin{tabular}{|c|c|c|c|c|c|}
\hline Reference & $\begin{array}{l}\text { Number } \\
\text { of patients }\end{array}$ & Cancer & Anticoagulant & $\begin{array}{c}\text { Duration of } \\
\text { therapy }\end{array}$ & Outcome \\
\hline Oda et al.[15] & 1 & $\begin{array}{l}\text { Stage IV lung } \\
\text { adenocarcinoma }\end{array}$ & Heparin, warfarin & 4 weeks & $\begin{array}{c}\text { Radiographic resolution at } 4 \\
\text { weeks }\end{array}$ \\
\hline $\begin{array}{l}\text { Iqbal and Sharma } \\
\text { [13] }\end{array}$ & 1 & $\begin{array}{l}\text { Metastatic colorectal } \\
\text { adenocarcinoma }\end{array}$ & LMWH, warfarin & 5 months & $\begin{array}{l}\text { Clinical improvement in } \\
\text { symptoms at } 5 \text { months }\end{array}$ \\
\hline Mutreja et al.[14] & 1 & $\begin{array}{l}\text { JAK2V617F mutation- } \\
\text { positive hematolymphoid } \\
\text { malignancy }\end{array}$ & $\begin{array}{l}\text { Heparin, warfarin, } \\
\text { dabigatran }\end{array}$ & 21 days & Death at 21 days \\
\hline Tuncel et al. [16] & 1 & $\begin{array}{c}\text { Advanced-stage small cell } \\
\text { lung cancer }\end{array}$ & LMWH & N/A & $\begin{array}{c}\text { Clinical improvement at } 1 \\
\text { month }\end{array}$ \\
\hline Marvin et al. [3] & 1 & $\begin{array}{c}\text { Metastatic renal cell } \\
\text { carcinoma (brain metastases) }\end{array}$ & Heparin & N/A & $\begin{array}{c}\text { Radiographic resolution and } \\
\text { death at } 4 \text { months (unknown } \\
\text { cause) }\end{array}$ \\
\hline Shimizu et al. [17] & 1 & Tongue cancer & Heparin & N/A & $\begin{array}{c}\text { Clinical and radiographic } \\
\text { improvement }\end{array}$ \\
\hline Akai et al. [18] & 1 & $\begin{array}{c}\text { Malignant melanoma with } \\
\text { meningeal dissemination }\end{array}$ & Urokinase, heparin & 24 hours & Recanalization of straight sinus \\
\hline Ho et al. [19] & 1 & Acute lymphoblastic leukemia & Heparin, warfarin & N/A & $\begin{array}{c}\text { Radiographic resolution at } 20 \\
\text { days }\end{array}$ \\
\hline Vargo et al. [1] & 1 & $\begin{array}{c}\text { Anaplastic gemistocytic } \\
\text { astrocytoma }\end{array}$ & Heparin, enoxaparin & N/A & $\begin{array}{l}\text { Stabilization and interval } \\
\text { improvement on MRI }\end{array}$ \\
\hline Eudo et al. [5] & 1 & Multiple myeloma & LMWH & $\mathrm{N} / \mathrm{A}$ & $\begin{array}{l}\text { Clinical improvement in } \\
\text { symptoms at } 1 \text { month }\end{array}$ \\
\hline Li et al. [20] & 1 & $\begin{array}{c}\text { Grade 2, stage IIIC serous } \\
\text { ovarian cancer }\end{array}$ & Enoxaparin & 5 weeks & Death at 5 weeks \\
\hline Chang et al. [21] & 1 & Acute myeloid leukemia, M1 & Enoxaparin, warfarin & $\mathrm{N} / \mathrm{A}$ & Clinical improvement in vision \\
\hline Wang et al. [22] & 1 & Acute lymphoblastic leukemia & Enoxaparin & 7 months & $\begin{array}{l}\text { Clinical and radiographic } \\
\text { improvement at six months }\end{array}$ \\
\hline Iurlaro et al. [23] & 9 & $\begin{array}{l}\text { Breast cancer x2, gastric } \\
\text { cancer, NHL x3, HL, kidney } \\
\text { cancer and melanoma, and } \\
\text { rhinopharyngeal cancer }\end{array}$ & $\begin{array}{l}\text { Unfractionated, } \\
\text { LMWH }\end{array}$ & N/A & $\begin{array}{l}\text { Based off of modified Rankin } \\
\text { scale (mRS): complete recovery } \\
\text { in } 4 \text { patients (mRS 0), mild } \\
\text { sequelae in } 4 \text { patients (mRS 1- } \\
\text { 2), and moderate sequelae in } \\
\text { one patient (mRS } 3 \text { ) }\end{array}$ \\
\hline $\begin{array}{l}\text { Karam and } \\
\text { Koussa [24] }\end{array}$ & 2 & $\begin{array}{l}\text { Germ-cell carcinoma of the } \\
\text { testis; poorly differentiated } \\
\text { pericardial carcinoma }\end{array}$ & $\begin{array}{l}\text { Unknown } \\
\text { anticoagulation; } \\
\text { heparin }\end{array}$ & 20 days & $\begin{array}{l}\text { Clinical and radiographic } \\
\text { improvement at } 1 \text { month; } \\
\text { unknown outcome }\end{array}$ \\
\hline Ross et al. [25] & 4 & $\begin{array}{l}\text { T-cell ALL; pre-B-cell ALL; } \\
\text { ALL; pre-B-cell ALL }\end{array}$ & $\begin{array}{l}\text { LMWH; unfractionated } \\
\text { heparin, LMWH, } \\
\text { warfarin; LMWH; } \\
\text { LMWH }\end{array}$ & $\begin{array}{l}7 \text { months; } \mathrm{n} / \\
\text { a; } 3 \text { months; } \\
4 \text { months }\end{array}$ & $\begin{array}{l}\text { Radiographic partial } \\
\text { recanalization; clinical } \\
\text { improvement in symptoms; } \\
\text { complete resolution on imaging } \\
\text { at } 1 \text { month; resolution on } \\
\text { imaging at } 1 \text { month }\end{array}$ \\
\hline Song et al. [26] & 1 & $\begin{array}{c}\text { Acute promyelocytic } \\
\text { leukemia }\end{array}$ & LMWH, warfarin & N/A & $\begin{array}{l}\text { Radiographic recanalization of } \\
\text { straight sinus with continued } \\
\text { occlusion of transverse and } \\
\text { confluens sinuum at } 1 \text { month }\end{array}$ \\
\hline $\begin{array}{l}\text { Imamura et al. } \\
\text { [27] }\end{array}$ & 2 & $\begin{array}{c}\text { B-precursor ALL; T-cell type } \\
\text { NHL }\end{array}$ & $\begin{array}{l}\text { No anticoagulation; } \\
\text { LMWH; ATIII } \\
\text { concentrate } \\
\text { supplementation }\end{array}$ & N/A; N/A & $\begin{array}{c}\text { Death at } 40 \text { days; complete } \\
\text { neurologic recovery }\end{array}$ \\
\hline Lee et al. [28] & 1 & Acute lymphoblastic leukemia & Heparin, warfarin & N/A & $\begin{array}{l}\text { Radiographic recanalization of } \\
\text { the superior sagittal sinus }\end{array}$ \\
\hline Ciccone et al. [29] & 1 & $\begin{array}{c}\text { Acute promyelocytic } \\
\text { leukemia }\end{array}$ & $\begin{array}{l}\text { Unfractionated heparin, } \\
\text { warfarin }\end{array}$ & & $\begin{array}{l}\text { Complete recovery from the } \\
\text { coma and almost complete } \\
\text { resolution of the sinuses } \\
\text { thrombosis. }\end{array}$ \\
\hline
\end{tabular}


TABLE 1: Continued.

\begin{tabular}{|c|c|c|c|c|c|}
\hline Reference & $\begin{array}{l}\text { Number } \\
\text { of patients }\end{array}$ & Cancer & Anticoagulant & $\begin{array}{c}\text { Duration of } \\
\text { therapy }\end{array}$ & Outcome \\
\hline $\begin{array}{l}\text { Motohashi et al. } \\
{[30]}\end{array}$ & 1 & Acute myeloid leukemia & Heparin, warfarin & $\mathrm{N} / \mathrm{A}$ & $\begin{array}{l}\text { Recanalization of straight sinus } \\
\text { but continued occlusion of the } \\
\text { right transverse and sigmoid } \\
\text { sinuses. No neurologic sequelae } \\
\text { at } 10 \text { months }\end{array}$ \\
\hline Corso et al. [31] & 2 & $\mathrm{Ph}+\mathrm{ALL} ; \mathrm{Ph}+\mathrm{ALL}$ & Heparin; heparin & N/A; N/A & $\begin{array}{l}\text { Radiographic resolution of } \\
\text { thrombus; progressive but slow } \\
\text { resolution of symptoms }\end{array}$ \\
\hline
\end{tabular}

Moreover, patients with malignancy frequently experience thrombocytopenia and other coagulopathies as a result of the cancer and/or cancer therapies, making treatment decisions even more difficult. Lack of treatment, however, can lead to thrombus propagation, neurologic sequelae, and death [4]. As such, an individualized approach to treatment is recommended.

Much like other VTEs, the medical management of CVT primarily consists of systemic anticoagulation to reduce the risk of thrombosis growth and to facilitate vessel recanalization. Several agents have been described in the treatment of CVT including heparin, low-molecular weight heparins (LMWHs), vitamin-K antagonists (VKAs), and direct oral anticoagulants (DOACs). In 2011, the American Heart Association (AHA) and American Stroke Association (ASA) released a set of guidelines on the diagnosis and management of CVT. Contained within the recommendations were guidelines on acute as well as long-term treatments. Acute treatment options included heparins, LMWHs, and VKAs with VKAs being the primary recommendation for longterm treatment [4]. Additionally, the European Academy of Neurology (EAN) released similar recommendations in 2017 [10]. Notable differences include the recommendation of LMWHs over heparin in the acute treatment for CVT based in part on a more recent randomized controlled trial suggesting better recovery with LMWH [11]. Specific guidelines were limited, however, for malignancy-related CVT in both societal recommendations.

The existing literature on agent of choice for cancerrelated CVT is primarily found in case reports. Several reports have been published demonstrating safety and positive outcomes of various anticoagulation regimens including heparin, LMWHs, and VKAs (Table 1) $[1,5,12,13-17,18-31]$. LMWHs have for several years been recommended over VKAs in malignancy-related VTE leading to the question of their superiority in malignancyrelated CVT [32]. To date, however, no prospective trials evaluating LMWHs over VKAs have occurred. Despite these established recommendations for malignancy-related VTE elsewhere, specific recommendations for treatment of malignancy-related CVT were neither elaborated upon in the 2011 AHA/ASA nor the 2017 EAN CVT treatment guidelines $[4,10]$.

The emergence of the direct oral anticoagulants (DOACs) in the treatment of malignancy-related VTE is a new focus of great interest with multiple studies and societal recommendations supporting DOAC use to treat DVT and pulmonary embolism [33-36]. The role of DOACs in the treatment of CVT, however, is unclear [37]. In one randomized controlled trial examining the safety and efficacy of dabigatran versus dose-adjusted warfarin in patients with CVT, dabigatran was at least as safe, if not safer, than warfarin with regard to major bleeding risk. Neither group experienced recurrent VTE, and both had similar degrees of recanalization $(60.0 \%$ in the dabigatran group and $67.3 \%$ in the warfarin group). Neither noninferiority nor superiority of either therapy could be demonstrated because of limited sample size [38].

Two case series exist describing the use of DOACs beyond the acute phase of treatment for CVT, one of which contained one patient with malignancy and CVT $[39,40]$. In these series, DOACs appeared to be associated with favorable outcomes without significant bleeding concerns though absence of recanalization in the patient with malignancy was noted. Neither the Hokusai VTE Cancer Investigators nor the SELECT-D trials investigating DOAC treatment of malignancy-related VTE included patients with CVT. Given also the association of venous hemorrhage with CVT, use of DOACs may pose a clinical issue given limited (albeit growing) options for reversal agents [4]. In the $2017 \mathrm{Eu}-$ ropean Academy of Neurology guidelines, DOAC therapy was not recommended for CVT based on low quality of evidence with a high risk for bias [10]. Further research is, therefore, needed into the efficacy and safety of DOACs for the management of malignancy-related CVT.

3.3. Duration of Therapy. The main goal of treatment beyond the acute therapy for CVT is prevention of thrombosis recurrence. New thrombosis following CVT has been reported as high $6.5 \%$ annually [41]. Optimal duration of long-term therapy to prevent recurrent CVT is often a question [42]. In the 2011 AHA/ASA and 2017 EAN CVT guidelines, a 3-12 month or indefinite anticoagulation duration was recommended depending on reversibility of the underlying etiology $[4,10]$. Provoked CVT with a transient risk factor may be treated for 3-6 months, while unprovoked CVT may be treated for 6-12 months. Other authors have suggested ranges of weeks to several months or durations based on radiologic resolution of the thrombus. In the setting of malignancy, however, in which the provoking event may not be reversed prior to 
suggested end of therapy, an individualized decision should be made weighing risks of ongoing treatment as well as the risk for recurrence.

Currently, there are no consensus guidelines for the specific management of malignancy-related CVT with a majority of evidence for treatment found in case reports or extrapolated from guidelines focused on nonmalignant CVT. At this time, there is not a clearly superior anticoagulant for the management of malignancy-related CVT though it may be reasonable to consider LMWHs over VKAs given existing data on LMWH superiority in preventing VTE recurrence in patients with malignancy. DOAC therapy for malignancy-related CVT is not recommended at this time given lack of studies of efficacy and safety though they may emerge as future treatment options. Optimal treatment duration is similarly unclear though should be extended beyond acute treatment for CVT barring contraindications.

\section{Conclusion}

As described in this case, anticoagulation was administered upon the initial diagnosis of CVT. Given ongoing malignancy, the patient was treated with therapeutic-dosing enoxaparin for nearly two years which was eventually terminated after the complications of anticoagulation were thought to outweigh the risk of thrombus recurrence. While malignancy-related CVT is a rare phenomenon, further prospective study is warranted to establish firmer guidelines for anticoagulation. Until this occurs, treatment and duration should remain individualized. Data to date support the use of heparin, LMWH, and warfarin in the treatment of malignancy-related CVT. DOAC efficacy and safety are unclear at this time for the treatment of malignancy-related CVT though should be a focus of future investigation.

\section{Conflicts of Interest}

The authors declare that they have no conflicts of interest.

\section{Acknowledgments}

The authors would like to thank Allison Burnett, PharmD, $\mathrm{PhC}, \mathrm{CACP}$, for her review and support of this article.

\section{References}

[1] J. A. Vargo, B. M. Snelling, E. R. Ghareeb et al., "Dural venous sinus thrombosis in anaplastic astrocytoma following concurrent temozolomide and focal brain radiotherapy plus bevacizumab," Journal of Neuro-Oncology, vol. 104, no. 2, pp. 595-598, 2011.

[2] J. J. Raizer and L. M. DeAngelis, "Cerebral sinus thrombosis diagnosed by MRI and MR venography in cancer patients," Neurology, vol. 54, no. 6, pp. 1222-1226, 2000.

[3] S. M. Silvis, S. Hiltunen, E. Lindgren et al., "Cancer and risk of cerebral venous thrombosis: a case-control study," Journal of Thrombosis and Haemostasis, vol. 16, no. 1, pp. 90-95, 2018.

[4] G. Saposnik, F. Barinagarrementeria, R. D. Brown et al., "Diagnosis and management of cerebral venous thrombosis," Stroke, vol. 42, no. 4, pp. 1158-1192, 2011.
[5] C. Eudo, J.-P. Cottier, A. Petit et al., "Cerebral venous thrombosis in an individual with multiple myeloma treated with lenalidomide," Journal of the American Geriatrics Society, vol. 59, no. 12, pp. 2371-2372, 2011.

[6] J. R. Ebright, M. T. Pace, and A. F. Niazi, "Septic thrombosis of the cavernous sinuses," Archives of Internal Medicine, vol. 161, no. 22, pp. 2671-2676, 2001.

[7] A. W. Kim and J. D. Trobe, "Syndrome simulating pseudotumor cerebri caused by partial transverse venous sinus obstruction in metastatic prostate cancer," American Journal of Ophthalmology, vol. 129, no. 2, pp. 254-256, 2000.

[8] L. R. Rogers, "Cerebrovascular complications in patients with cancer," Seminars in Neurology, vol. 24, no. 4, pp. 453-460, 2004.

[9] G. J. Caine, P. S. Stonelake, G. Y. H. Lip, and S. T. Kehoe, "The hypercoagulable state of malignancy: pathogenesis and current debate," Neoplasia, vol. 4, no. 6, pp. 465-473, 2002.

[10] J. M. Ferro, M.-G. Bousser, P. Canhão et al., "European stroke organization guideline for the diagnosis and treatment of cerebral venous thrombosis-endorsed by the European Academy of Neurology," European Journal of Neurology, vol. 24, no. 10, pp. 1203-1213, 2017.

[11] U. K. Misra, J. Kalita, S. Chandra, B. Kumar, and V. Bansal, "Low molecular weight heparin versus unfractionated heparin in cerebral venous sinus thrombosis: a randomized controlled trial," European Journal of Neurology, vol. 19, no. 7, pp. 1030-1036, 2012.

[12] E. Marvin, J. Synkowski, and M. Benko, "Tumor cerebri: metastatic renal cell carcinoma with dural venous sinus compression leading to intracranial hypertension; a case report," Surgical Neurology International, vol. 8, no. 1, p. 175, 2017.

[13] N. Iqbal and A. Sharma, "Cerebral venous thrombosis: a mimic of brain metastases in colorectal cancer associated with a better prognosis," Case Reports in Oncological Medicine, vol. 2013, Article ID 109412, 3 pages, 2013.

[14] D. Mutreja, R. Saxena, T. S. V. G. Tilak, V. Tewari, N. Moorchung, and B. Nandi, "A 37-year-old male with extensive cerebral venous thrombosis: clinicopathological correlation of a rare case," Indian Journal of Pathology and Microbiology, vol. 61, no. 2, pp. 219-224, 2018.

[15] N. Oda, M. Sakugawa, A. Bessho et al., "Cerebral venous sinus thrombosis concomitant with leptomeningeal carcinomatosis, in a patient with epidermal growth factor receptor-mutated lung cancer," Oncology Letters, vol. 8, no. 6, pp. 2489-2492, 2014.

[16] T. Tuncel, A. Ozgun, L. Emirzeoğlu et al., “Broca’s aphasia due to cerebral venous sinus thrombosis following chemotherapy for small cell lung cancer: a case report and review of literature," Oncology Letters, vol. 9, no. 2, pp. 937-939, 2015.

[17] T. Shimizu, A. Musha, Y. Takayama, and S. Yokoo, "A case of cerebral venous sinus thrombosis associated with chemoradiation therapy for oral cancer," International Journal of Oral and Maxillofacial Surgery, vol. 46, p. 293, 2017.

[18] T. Akai, N. Kuwayama, T. Ogiichi, M. Kurimoto, S. Endo, and A. Takaku, "Leptomeningeal melanoma associated with straight sinus thrombosis-case report," Neurologia MedicoChirurgica, vol. 37, no. 10, pp. 757-761, 1997.

[19] C. L. Ho, Y. C. Chen, C. Y. Chen, and T. Y. Chao, "Cerebral dural sinus thrombosis in acute lymphoblastic leukemia with early diagnosis by fast fluid-attenuated inversion recovery (FLAIR) MR image: a case report and review of the literature," Annals of Hematology, vol. 79, no. 2, pp. 90-94, 2000. 
[20] H. K. Li, V. Harding, R. Williamson, S. Blagden, H. Gabra, and R. Agarwal, "Cerebral sinus thrombosis and leptomeningeal carcinomatosis in a patient with ovarian cancer," Journal of Clinical Oncology, vol. 30, no. 2, pp. e19-e20, 2012.

[21] H. Chang, T.-L. Lin, W.-J. Ho, and L.-A. Hsu, "Acute myeloid leukemia associated with acute myocardial infarction and dural sinus thrombosis: the possible role of leukemia-related hyperhomocysteinemia," Journal of the Chinese Medical Association, vol. 71, no. 8, pp. 416-420, 2008.

[22] T.-Y. Wang, H.-J. Yen, G.-Y. Hung, M.-Y. Hsieh, and R.-B. Tang, "A rare complication in a child undergoing chemotherapy for acute lymphoblastic leukemia: superior sagittal sinus thrombosis," Journal of the Chinese Medical Association, vol. 74, no. 4, pp. 183-187, 2011.

[23] S. Iurlaro, A. Silvani, M. Mauri et al., "Headache in cerebral venous thrombosis associated with extracranial tumors: a clinical series," Neurological Sciences, vol. 36, no. S1, pp. 149-151, 2015.

[24] C. Karam and S. Koussa, "Cerebral dural sinus thrombosis following cisplatin chemotherapy," Journal of Clinical Neuroscience, vol. 15, no. 11, pp. 1274-1275, 2008.

[25] C. S. Ross, T. M. Brown, S. Kotagal, and V. Rodriguez, "Cerebral venous sinus thrombosis in pediatric cancer patients," Journal of Pediatric Hematology/Oncology, vol. 35, no. 4, pp. 299-302, 2013.

[26] L.-X. Song, H.-y. Lu, C.-k. Chang, X. Li, and Z. Zhang, "Cerebral venous and sinus thrombosis in a patient with acute promyelocytic leukemia during all-trans retinoic acid induction treatment," Blood Coagulation \& Fibrinolysis, vol. 25, no. 7, pp. 773-776, 2014.

[27] T. Imamura, A. Morimoto, R. Kato et al., "Cerebral thrombotic complications in adolescent leukemia/lymphoma patients treated with L-asparaginase-containing chemotherapy," Leukemia \& Lymphoma, vol. 46, no. 5, pp. 729-735, 2005.

[28] J.-H. Lee, S.-W. Kim, and J. Sung Kim, "Sagittal sinus thrombosis associated with transient free protein S deficiency after L-asparaginase treatment: case report and review of the literature," Clinical Neurology and Neurosurgery, vol. 102, no. 1, pp. 33-36, 2000.

[29] M. Ciccone, G. M. Rigolin, G. M. Viglione, M. Borrelli, M. L. Serino, and A. Cuneo, "Thrombosis of the cerebral veins and sinuses in acute promyelocytic leukemia after all-trans retinoic acid treatment: a case report," Blood Coagulation \& Fibrinolysis, vol. 19, no. 7, pp. 721-723, 2008.

[30] K. Motohashi, M. Hagihara, S. Ito et al., "Cerebral venous sinus thrombosis after allogeneic stem cell transplantation," International Journal of Hematology, vol. 91, no. 1, pp. 154156, 2010.

[31] A. Corso, C. Castagnola, and C. Bernasconi, "Thrombotic events are not exclusive to the remission induction period in patients with acute lymphoblastic leukemia: a report of two cases of cerebral sinus thrombosis," Annals of Hematology, vol. 75, no. 3, pp. 117-119, 1997.

[32] C. Kearon, E. A. Akl, J. Ornelas et al., "Antithrombotic therapy for VTE disease," Chest, vol. 149, no. 2, pp. 315-352, 2016.

[33] G. E. Raskob, N. van Es, P. Verhamme et al., "Edoxaban for the treatment of cancer-associated venous thromboembolism," New England Journal of Medicine, vol. 378, no. 7, pp. 615-624, 2018.

[34] A. M. Young, A. Marshall, J. Thirlwall et al., "Comparison of an oral factor xa inhibitor with low molecular weight heparin in patients with cancer with venous thromboembolism: results of a randomized trial (SELECT-D)," Journal of Clinical Oncology, vol. 36, no. 20, pp. 2017-2023, 2018.

[35] E. Cosma and J. J. Prunty, "Direct oral anticoagulant in cancers patients," U.S. Pharmacist, vol. 43, no. 8, pp. 2-11, 2018.

[36] N. S. Key, K. Bohlke, and A. Falanga, "Venous thromboembolism prophylaxis and treatment in patients with cancer: ASCO clinical practice guideline update," Journal of Oncology Practice, vol. 15, no. 12, pp. 661-664, 2019.

[37] T. Duman, D. Uluduz, I. Midi et al., "A multicenter study of 1144 patients with cerebral venous thrombosis: the VENOST study," Journal of Stroke and Cerebrovascular Diseases, vol. 26, no. 8, pp. 1848-1857, 2017.

[38] J. M. Ferro, J. M. Coutinho, F. Dentali et al., "Safety and efficacy of dabigatran etexilate vs dose-adjusted warfarin in patients with cerebral venous thrombosis: a randomized clinical trial," JAMA Neurology, vol. 76, no. 12, p. 1457, 2019.

[39] C. Geisbüsch, D. Richter, C. Herweh, P. A. Ringleb, and S. Nagel, "Novel factor xa inhibitor for the treatment of cerebral venous and sinus thrombosis," Stroke, vol. 45 , no. 8 , pp. 2469-2471, 2014.

[40] M. D. Mendonça, R. Barbosa, V. Cruz-e-Silva, S. Calado, and M. Viana-Baptista, "Oral direct thrombin inhibitor as an alternative in the management of cerebral venous thrombosis: a series of 15 patients," International Journal of Stroke, vol. 10, no. 7, pp. 1115-1118, 2015.

[41] J. M. Ferro, P. Canhão, J. Stam, M.-G. Bousser, and F. Barinagarrementeria, "Prognosis of cerebral vein and dural sinus thrombosis," Stroke, vol. 35, no. 3, pp. 664-670, 2004.

[42] V. Desa and R. Green, "Cavernous sinus thrombosis: current therapy," Journal of Oral and Maxillofacial Surgery, vol. 70, no. 9, pp. 2085-2091, 2012. 